\title{
Judicial Law-Making: Unlocking the Creative Powers of Judges in Terms of Section 39(2) of the Constitution
}

\section{P.E.R}

Pioneer in peer-reviewed, open access online law publications.

\section{Authors}

Annie Singh and Moreblessing Zaryl Bhero

Affiliation

University of KwaZulu-Natal, South Africa

\section{Email singhat@ukzn.ac.za} zbhero@werkermans.com

Date published

16 November 2016

\section{Editor Prof S du Toit}

How to cite this article

Singh A and Bhero MZ "Judicial Law-Making: Unlocking the Creative Powers of Judges in Terms of Section 39(2) of Constitution" PER / PELJ 2016(19) - DOI

http://dx.doi.org/10.17159/17273781/2016/v19i0a1504

\section{Copyright}

\section{(i)}

DOI

http://dx.doi.org/10.17159/17273781/2016/v19i0a1504

\begin{abstract}
The law-making role of judges has always been the subject of much controversy. For a good many a year and especially during the apartheid regime, the approach to statutory interpretation that dominated the South African courts was the orthodox textual position. According to the textualists, as they were referred to, the position that was adopted was that legislation was to be interpreted within the framework of the words used by the legislature. The courts were not empowered to make any modifications, alterations or additions to the legislative text, as this function was solely the responsibility of the legislature. The paradigmatic shift in emphasis since 1994 from a system of parliamentary sovereignty to constitutional supremacy changed this position significantly. The key consideration of statutory interpretation was that the aim and purpose of legislation was to be considered with the values of the Constitution forming the over-arching principle in the process of interpretation. The courts were enjoined to reconcile the purpose of the legislation with the provisions of the Constitution, and in particular, the Bill of Rights. The emerging view in support of the purposive or the teleological theory has been that judges do indeed have a law-making function in the process of interpretation. Since the early 1990's, it has been observed that the judiciary has been able to assert its influence on the development of the law and the emerging jurisprudence, as a result of the powers derived from the Constitution, and in particular section 39(2). The article examines the extent to which the judiciary can use this power in a post-democratic constitutional era, in South Africa, to achieve justice. From the repository of cases, which forms the basis of the discussion, the article proposes a set of factors that ought to be heeded by our courts in the application of section 39(2).
\end{abstract}

\section{Keywords}

Concretisation; parliamentary sovereignty; constitutional supremacy; textual interpretation; teleological interpretation; value-orientated approach; reading-in; reading-down; severance; judicial activism. 


\section{Introduction}

The Constitution of the Republic of South Africa ${ }^{1}$ has had a phenomenal influence on South African society as a whole and the emerging jurisprudence in relation thereto, acting as a bridge from the notorious apartheid regime and leading to the new democratic constitutional dispensation. Over the last two decades there has been a rapid development of our constitutional jurisprudence, largely facilitated by the decisions made by the courts. In developing our jurisprudence, the courts have had a number of challenging decisions to consider. A few of these form the basis of the discussion on judicial law-making in the current constitutional order, and are considered here.

Due to the oppressive history of South Africa, the public confidence in the judiciary was tarnished considerably and it was only with the introduction of the Interim Constitution ${ }^{2}$ that the judiciary's work in changing this perception started taking effect. However, the responsibility of the courts to develop a just and coherent constitutional jurisprudence and to foster public confidence in the judiciary does not lie solely with the judiciary. This duty has to be regarded as a shared responsibility amongst legal academics, scholars, practitioners, and ordinary citizens who must participate in "constructive dialogue with the courts, other persons and institutions about which interpretations of the Constitution will best realise its transformative purpose". ${ }^{3}$

This article examines the philosophies underlying judicial reasoning as well as how the approach of South African courts has influenced the methods of interpretation that have been applied. From an analysis of the emerging jurisprudence as a result of the methodology applied, the aim of the article therefore is to establish the factors that ought to be considered

* Annie Singh. LLB (UDW) LLM (UDW) Phd (UKZN). Lecturer, School of Law, University of KwaZulu-Natal. Email: singhat@ukzn.ac.za.

** Moreblessing Zaryl Bhero. Final year LLB student, School of Law, University of KwaZulu-Natal. Email: zbhero@werkermans.com. The authors would like to extend their gratitude to George Devenish, Professor Emeritus at the University of KwaZuluNatal for his valuable input and comments made on earlier drafts of the article.

1 The Constitution refers to the Constitution of the Republic of South Africa, 1996 (Constitution) unless indicated otherwise.

2 Constitution of the Republic of South Africa Act 200 of 1993 (Interim Constitution).

3 Cornell and Friedman 2002 http://bit.ly/24FjjPu. 
by judges when exercising their powers in terms of section 39(2) of the Constitution. ${ }^{4}$ This forms the thrust of the article.

\section{The role of judges}

\subsection{Concretising the law}

The interpretation of law by the judiciary can be deemed to be the final stage in the legislative process. According to the concept of concretisation, the process of law-making is not completed by the promulgation of legislation. What is required is a harmonisation of the abstract legislative text with the facts of the case through interpretational methods, within the framework of the Constitution or relevant law. What this means in effect is that the judiciary does in fact have a "peripheral and subordinate lawmaking function". ${ }^{5}$ Devenish seems to agree with this view and suggests further that there is an implied

delegation of quasi-legislative competence to the judicial arm of government. Consequently, the courts play a vital and unique role in developing and formulating the law. ${ }^{6}$

This is largely due to the fact that there will inevitably be a certain amount that the legislature may have left out during the drafting of legislation. This is referred to as the "drafting device of ellipsis"7 and accordingly some established legal principles, particularly administrative and constitutional law principles, may be over-looked by parliament. This is when the delegated "quasi-legislative" powers of the judiciary would come into play. ${ }^{8}$ It is further submitted that

since all cases cannot be foreseen or expressed, it is necessary that when general decrees of law come to be applied in particular cases, there should be some powers vested, of defining those circumstances which (had they been foreseen) the legislator himself would have expressed. ${ }^{9}$

4 Section 39(2) of the Constitution states that "when interpreting any legislation, and when developing the common law or customary law, every court, tribunal or forum must promote the spirit, purport and objects of the Bill of Rights".

5 Botha Statutory Interpretation 161.

6 Devenish Interpretation of Statutes 6.

7 Bennion Statutory Interpretation 240.

8 Cross Statutory Interpretation 166.

9 Devenish Interpretation of Statutes 40. 
In the case of Corocraft Ltd $v$ Pan American Airways, ${ }^{10}$ Donaldson $\mathrm{J}$ explained the role of judges in the interpretation of legislation and in a manner consistent with the theory of "concretisation" as follows:

In the performance of this duty the judges do not act as computers into which are fed statutes and the rules for construction of Statutes and from which issue forth the mathematically correct answer. The Interpretation of Statutes is a craft as much as a science and the judges, as craftsmen, select and apply appropriate rules as the tools of their trade. They are not legislators, but finishers and polishers of legislation which comes to them in a state requiring varying degrees of further processing.

Indeed the above quotation succinctly sums up the role of the judge in the process of law-making. Due to the fact that judges are regarded as being representatives of the judicial system, the manner in which they execute their duties, particularly with regard to the interpretation and application of the law, has always been a subject of interest. There has certainly been an upsurge of interest with the advent of the new constitutional dispensation and in particular the introduction of section 39. The application of section 39 and the influence of the theories related thereto are dealt with in more detail hereunder. ${ }^{11}$ Nevertheless, some of the more popular philosophical theories on the role of judges are also relevant to the discussion, and a brief analysis of each is presented.

\section{Philosophical theories on the role of judges}

To fully appreciate the role of judges, an analysis of some of the more popular philosophical theories is useful. The article focuses on three contentious issues on the role of judges from influential legal philosophers. The first is Ronald Dworkin, who is renowned for his theory of "Law as Integrity". He developed an idea of "constructive interpretation" and contended that judges must always seek to derive the best solution in cases taking into consideration the legal doctrine and political structure in a community. In extending this theory, he created a mythical judge, Hercules $J$, who according to him always derived the correct decision, for which he argued there was always one best-fitting conclusion. ${ }^{12}$ This required an interpretation of law as a whole. Consideration has to be given to the entire body of law and this includes evaluating the relevant legal principles and theories in the process of interpretation. According to

Corocraft Ltd v Pan American Airways 19733 (WLR) 714732.

See the discussion in 5.5 Cases impacting on policy issues.

Rosenfield Law, Justice, Democracy 184. 
Dworkin, judges should always strive to emulate Hercules $J$ in the cases that they decide. ${ }^{13}$

The legal positivists on the other hand were of the view that the interpretation of law was a mechanical process in which no value judgements or discretion are exercised by the judge, and that morals are completely separated from law. ${ }^{14}$ Herbert Hart, an acclaimed positivist who has been widely quoted in this regard, has stated that "law is not morality; do not let it supplant morality". ${ }^{15}$ Therefore, it was argued that the role of the judges is simply to derive the intention of the legislature through the interpretation of the text, and should have less regard to extrinsic methods of interpretation. As a result of focusing on the literal theory and giving effect to the ordinary grammatical meaning of the words, courts were able to give effect to harsh, unjust apartheid legislation.

The view of the American realists may be deemed to be somewhat more radical. The basis of their reasoning is that judges rarely derive a conclusion from a consideration of legal principles but instead their decisions are influenced by each judge's prejudices. Legal principles, it is argued, are merely used to justify the biased conclusion. Therefore, it is their submission that law is actually made by the judges and what the law is, is thus decided by the presiding judge's political, economic and moral views. ${ }^{16}$ Judge Jerome Frank, who is also known as the enfant terrible ${ }^{17}$ of the realists, is convinced that the approach to the judicial process is:
A myth - a false affirmation without complete knowledge of its falsity ... when judges and lawyers announce that judges can never validly make law, they are not engaged in fooling the public; they have successfully fooled themselves. ${ }^{18}$

This view is perhaps not very popular in the legal fraternity. Comparatively, it would seem, however, that the views held by the positivists and Dworkin have been more favourably received in the South African legal system. While prior to 1994 the court's approach was more reflective of the positivists' ideology that law and morality were to be regarded as separate concepts, this changed significantly with the introduction of the 1996 Constitution. Post 1994, Dworkin's theory of constructive interpretation

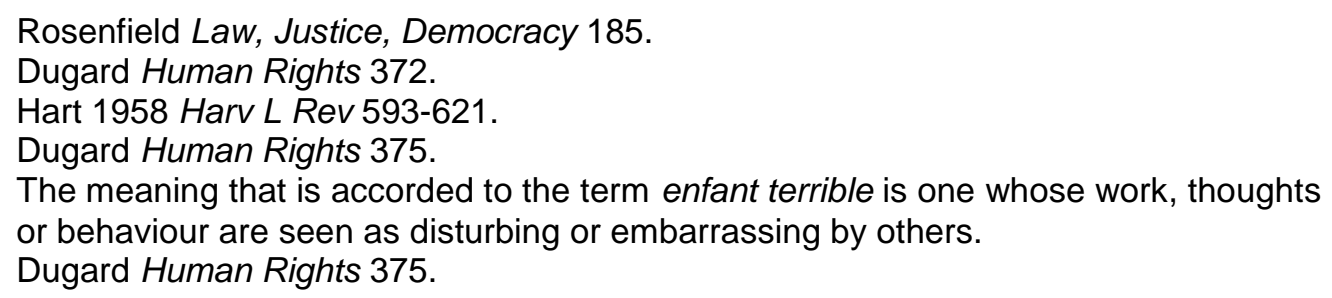


would appear to be more accurate and relevant. The role of judges and their influence on South African jurisprudence is traced from an examination of relevant case-law. ${ }^{19}$ The reason for effecting such a comparison is to identify possible factors that ought to be heeded by judges when applying section 39(2) in the process of interpretation.

\section{$4 \quad$ An overview of the position prior to 1994}

\subsection{The doctrine of parliamentary sovereignty}

Prior to the Constitution, South Africa applied the doctrine of parliamentary sovereignty. According to Dicey, the concept is defined as:

\footnotetext{
Neither more nor less than this, namely that Parliament has under the English Constitution the right to make or unmake any law whatsoever, and further that no person or body is recognised by the Law of England as having a right to override or set aside the Legislation of Parliament. ${ }^{20}$
}

What is evident is that this doctrine was imposed on South Africa during the British colonial rule. Nevertheless, even though other states in Africa were also subjected to British rule, none had to succumb to the infamous and derogatory racial laws to the same extent as did South Africa. In accordance with the doctrine of parliamentary sovereignty, during the apartheid era the South African courts in general applied mainly a strict literal and textual approach when interpreting the law and deciding on cases. Therefore, the courts were not involved in law-making as propounded by Dworkin's theory of "constructive interpretation", but rather they were limited to interpreting the text and enforcing the will of parliament without any scrutiny as to how fair or just the laws were. This is in keeping with the expression iudicis est ius dicere sed non dare, which means that "the duty of the judge is to apply the law, not to make it". ${ }^{21}$ Therefore it would seem that there was little scope for judicial review and judicial activism by the courts.

\subsection{The effect of the doctrine of parliamentary sovereignty on South African law}

The doctrine of parliamentary sovereignty has had far-reaching consequences on South African law. In applying the doctrine during apartheid, the judiciary allowed the government of the day to use it as an instrument to achieve its own goals. The gross infringements of human

\footnotetext{
See the discussion of cases in 5.5 Cases impacting on policy issues.

Dicey Introduction to the Study of Law 70.

Botha Statutory Interpretation 160.
} 
rights subsequently led to a loss of confidence in the judiciary during the apartheid era. The courts adopted a distinction between the legislature's function and the judiciary's function and regarded it as their duty to analyse and interpret the will of Parliament "but not to 'reason why'". ${ }^{22}$ The emphasis was on procedural fairness rather than substantive fairness. This view, as discussed earlier, strongly reflected the thinking of the legal positivists, who contended that law and morality should not overlap unless such morality is enforced by legislation which has been duly passed by parliament. Thus the role of the judge accordingly was to interpret the legal text and nothing more.

In the case of Collins $v$ Minister of the Interior, ${ }^{23}$ a famous case that was decided during apartheid, Centilivres CJ specifically stated that:

\section{If the provisions of a law are clear, we, as a court, are not concerned with the propriety of the legislation or policy of the legislature, our duty is to minister and interpret it as we find it.}

The approach referred to was also applied in many other cases, ${ }^{24}$ clearly left a lot to be desired, and did in fact inhibit the development of the law. It is argued that the very essence of judicial duty is the delivery of justice. However, during apartheid this was clearly compromised by the judiciary. The former Chief Justice Mahomed remarked that the judiciary neither has the power of the purse nor the sword and its power is derived from the esteem in which it is held within "the psyche and soul of a nation". ${ }^{25}$ Accordingly, in order to foster public confidence in the courts, historical and political factors must be taken into account. This must be done with a forward-looking mind-set with the aim of promoting equality and freedom and the highly protected rights in the Bill of Rights so as to ensure that the process is in accordance with the values and principles enshrined in the Constitution.

Friedman 1961 Colum L Rev 823.

Collins v Minister of the Interior 19571 SA 552 (A) 567.

24 Minister of Posts and Telegraphs $v$ Rasool 1934 AD 167; Stanton $v$ Minister of Justice 19643 SA 354 (T); S v Wood 19761 SA 703 AD; S v Tobias 19672 SA 165 (C); $S$ v Hjul 19642 SA 635 (C). 


\section{$5 \quad$ An overview of the position post 1994}

\subsection{Empowerment of the judiciary}

With most African States, it has been noted that the judiciary has been over-shadowed by the executive and legislative branches of government. ${ }^{26}$ This was especially so in South Africa with the system of parliamentary sovereignty, as has already been alluded to. The shift in emphasis from parliamentary sovereignty to constitutional supremacy since the early 1990's has changed this position significantly, with the judiciary being able to assert its influence on the development of law and the emerging jurisprudence as a result of the powers derived from the Constitution. It is argued, however, that the empowerment of the judiciary can only be truly realised where the judiciary uses its powers to negate the authoritarian impulses of elected politicians and acts "boldly and decisively to enforce both the letter and the spirit of the law". ${ }^{27}$ The South African Constitution has been manifestly instrumental in enabling the judiciary to give effect to the spirit of the law, in terms of the following relevant provision. Section $2^{28}$ of the Constitution, which declares that the Constitution is the supreme law of the Republic of South Africa, read together with section $165,{ }^{29}$ which vests judicial authority in the courts, as well as section $173,{ }^{30}$ which provides for the inherent power of the courts to protect and regulate their own processes, theoretically allows for the courts to "act boldly and decisively to enforce both the letter and the spirit of the law". ${ }^{31}$ More relevant to the debate, however, is section 39(2) of the Constitution, which provides that:

When interpreting any legislation, and when developing the common law or customary law, every court, tribunal or forum must promote the spirit, purport and objects of the Bill of Rights.

Consequently, the courts must make value judgements when engaging in the interpretation and application of law. Botha submits that "the courts are

26 Quansah and Fombad 2009 http://bit.ly/24E8Ffj.

27 Quansah and Fombad 2009 http://bit.ly/24E8Ffj.

28 Section 2 of the Constitution provides: "The Constitution is the supreme law of the Republic; law or conduct inconsistent with it is invalid, and the obligations imposed by it must be fulfilled."

29 Section 165(1) of the Constitution provides:"The judicial authority of the Republic is vested in the courts."

30 Section 173 of the Constitution provides:"The Constitutional Court, Supreme Court of Appeal and High Court have the inherent power to protect and regulate their own process, and to develop the common law, taking into account the interests of justice."

31 Quansah and Fombad 2009 http://bit.ly/24E8Ffj. 
the guardians of the values underlying the Constitution". ${ }^{32}$ Therefore, in any matter that comes before the court, the mandate of the courts is to ensure that they enforce and protect the values embodied in the Constitution. As a result thereof there has been a noticeable paradigmatic shift from a literal or textual methodology to a more value-based or a teleological mode of interpretation.

\title{
5.2 Application of Section 39(2)
}

\subsubsection{The teleological approach to interpretation}

It is evident that section 39(2) clearly mandates a more teleological or a value-orientated approach to the process of the interpretation of law. This is diametrically opposite to the literal or textual approach that was adopted prior to the Constitution under the parliamentary sovereignty, as has been explicated earlier. In the Matiso ${ }^{33}$ case which was decided under the Interim Constitution, Sachs $J$ gave the following explanation of the teleological approach to constitutional interpretation:

\begin{abstract}
The values that must suffuse the whole process (of interpretation) are derived from the concept of an open and democratic society based on freedom and equality, several times referred to in the constitution. The notion of an open and democratic society is thus not merely aspirational or decorative, it is normative furnishing the matrix of ideals within which we work, the source from which we derive the principles and rules we apply, and the final measure we use for testing the legitimacy of impugned norms and conduct. We should not engage in purely formal or academic analysis, nor simply restrict ourselves to ad hoc technicism, but rather focus on what has been called a synergetic relation between the values underlying the guarantees of fundamental rights and the circumstances of the particular case.
\end{abstract}

Further, in Makwanyane ${ }^{34}$ the court stated the following with regard to the interpretation of the provisions of the Bill of Rights:

Whilst paying due regard to the language that has been used, the interpretation must be generous and purposive and give ... expression to the underlying values of the Constitution.

What can be ascertained from the above is that the judges have certainly been afforded a degree of latitude or discretion when deciding cases. This flexibility allows for the courts to adopt an "extrinsic method of interpretation" which, according to Sowell, entails the importation of

\footnotetext{
32 Botha Statutory Interpretation 164.

33 Coetzee $v$ Government of the Republic of South Africa, Matiso v Commanding Officer, Port Elizabeth Prison 199510 BCLR 1382 (CC) para 46.

$34 \quad$ S v Makwanyane 19953 SA 391 (CC) para 9.
} 
considerations deemed to be of equal value to the Constitution so as to decipher and give effect to the intention of the Constitution's drafters. ${ }^{35}$

Therefore, the teleological approach does not solely focus on the purpose or the intention of the legislature but actually takes into account all the relevant deliberations that may be applied. It looks at the law as a whole and aspires to a higher coherence.

This resonates with Dworkin's theory of constructive interpretation, which requires that judges look at the law as a whole and come to the best decision possible when interpreting the law. In line with the teleological approach and theory of constructive interpretation, the Constitutional Court has held that the Constitution

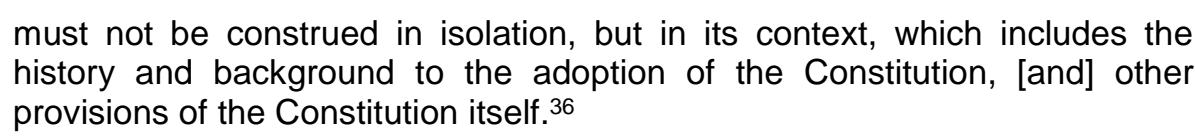

It is submitted that the teleological approach requires that judges consider the history of the country and the values that are embraced by the Constitution which have been informed by this history when interpreting the law. From this, the courts are then required to adopt what Du Plessis refers to as a "forward looking interpretation, based on what can be learnt from the past". ${ }^{37}$ This essentially results in judicial activism, which is a concept that advocates for such interpretation by the judges as reflects the current conditions and values of society. This concept includes

the practice by judges of disallowing policy choices by other governmental officials or institutions that the Constitution does not clearly prohibit. ${ }^{38}$

In applying the law in the manner described, judges must have regard to the circumstances that surrounded the adoption of the Constitution, the enshrined values, and must give due consideration to the social, political and economic factors.

The question that arises as a consequence thereof is how this discretion is limited and used in such a manner to ensure that the Constitution and values that it upholds, as well as the doctrine of the separation of powers, (including the necessary checks and balances) are observed. The ensuing discussion attempts to address this dilemma.

\footnotetext{
35 Sowell Judicial Activism Reconsidered 23.

36 Soobramoney $v$ Minister of Health KwaZulu-Natal 19981 SA 765 (CC).

37 Du Plessis Re-Interpretation of Statutes 249.

38 Graglia 1996 Harv J L \& Pub Pol'y 293-296.
} 


\subsection{Counter majoritarian difficulty}

Where courts exercise a power to scrutinise the conformity of ordinary laws with constitutional imperatives, they

define the boundary of law making authority of the legislature. This may involve not only striking down legislation but also developing the common law, thus detracting the legislature's law-making power. Both functions clash with the expression of the will of the majority, which is central to a democratic system. ${ }^{39}$

Bickel describes this as the "counter-majoritarian difficulty" and states that judicial review is a counter majoritarian force (with reference to the United States of America), and further that "when the Supreme Court declares unconstitutional a legislative act it thwarts the will of representatives of the actual people of the here and now". ${ }^{40}$ This is a paradox, considering that the intentions of an elected legislature can be thwarted by a few unelected judicial officers. It is then clear from this that the courts in exercising this power would need to be cautious not to exceed or abuse their powers as "undue adventurism can be as damaging as excessive judicial timidity". ${ }^{41}$ This "counter-majoritarian difficulty" would seem to be one of the more serious problems the courts face when they engage in judicial activism. The Constitutional Court in its attempts to fulfil its mandate in terms of section 39(2) has in a number of cases gone against the will of the majority and perhaps to a certain extent even risked the depreciation of the confidence of the public in the courts.

Two particular cases are relevant in this regard. The first to be considered is the Makwanyane ${ }^{42}$ case, which was on the constitutionality of section 277(1) of the Criminal Procedure Act, ${ }^{43}$ which allowed for the imposition of the death penalty for persons charged and convicted of murder. Despite public outcry (this included an outcry for a referendum on this issue) and the rising crime rate in South Africa at that time, the Constitutional Court declared this section unconstitutional and abolished the death penalty, thereby disregarding public opinion. Chief Justice Chaskalson further stated that "public opinion should not deter the judiciary from interpreting and upholding constitutional provisions without fear or favour". According to him, if public opinion was decisive, there would be no need for

\footnotetext{
39 Masiya v Director of Public Prosecutions (Pretoria) 20075 SA 30 (CC).

$40 \quad$ Bickel Least Dangerous Branch 16-17.

41 Stated by Justice Albie Sachs in Prince $v$ President of the Law Society of the Cape of Good Hope 20022 SA 194 (CC) para 156.

42 S v Makwanyane 19953 SA 391 (CC) para 9.

43 Criminal Procedure Act 51 of 1977.
} 
constitutional adjudication. The other case in point is that of Fourie. ${ }^{44}$ In this case the Constitutional Court declared that section 30(1) of the Marriage $A c t^{45}$ was unconstitutional as it failed to recognise the right of gay couples to marry. Although in doing this the Court was fulfilling its mandate to protect fundamental rights, it brought forth a "countermajoritarian difficulty", as some public opposition was expressed at the time.

In these two cases the Court vigorously exercised judicial activism and evidently unlocked its creative powers in terms of section 39(2) of the Constitution. The Court took into account the history of South Africa, inequality and the prejudicial treatment of certain groups, and reconciled this with the values that underlie the Constitution and the purpose and objectives of the Constitution thereof. There was some resistance to this new system and some questioning of the legitimacy of the judiciary. Perhaps this could have been anticipated, since for decades the judiciary had been inclined to be largely conservative and had subscribed to positivist views. The Court was seen as having perhaps taken the position of the law-maker and disregarded the "intentions" of the democratically elected parliament. However, despite this, the result has been the positive development of our constitutional jurisprudence and human rights protection.

Although these decisions may have been met with some reservations by the general public, the legitimacy of the court, it is submitted, was not undermined. It is argued that because these decisions only aided in advancing and protecting human rights (especially the rights of minority groups) this constituted progressive judicial activism and accordingly the argument is that "progressive judicial activism is not fundamentally harmful to the legitimacy of the courts". ${ }^{46}$ Although this was in essence not regarded as being harmful to the legitimacy of the courts, it begs the question as to whether the courts were within their power in terms of section 39(2) to make such decisions.

\subsection{The judiciary and policy}

It seems almost inevitable that courts will make decisions that will impact to a greater or a lesser extent on policy. This was quite clearly illustrated in

\footnotetext{
44 Minister of Home Affairs v Fourie; Lesbian and Gay Equality Project $v$ Minister of Home Affairs 20061 SA 524 (CC).

45 Marriage Act 25 of 1961.

46 Diala 2007 http://bit.ly/1SZ17c6.
} 
Makwanyane and Fourie referred to above. The very nature of judicial review and the concept of checks and balances require that the courts scrutinize the decisions made by other branches of government and what emanates as a result thereof is that these decisions cannot be separated from politics.

Du Plessis argues that:

A bill of rights judicialises politics because it requires the judiciary to act as an independent referee who keeps (party) political actors to the basic 'rules of the political game' enshrined in the bill of rights. This in turn calls for political skills on the part of the referee itself - a politicisation of the judiciary in other words. ${ }^{47}$

Further, Dugard similarly argues that even if "judges may dislike making policy decisions", this is a "necessary part of the judicial function in any advanced, civilized legal system". ${ }^{48}$ The judiciary ought to also realise that it does make the law, although this may be so only interstitially. Consequently, it is involved in making policy decisions and is a part of the South African political process. ${ }^{49}$ Even though Dugard wrote many years before the adoption of the Constitution, his submissions could not be more relevant today.

\subsection{Cases impacting on policy issues}

What can be gleaned from an examination of case-law is that in some cases the Constitutional Court has indeed gone so far as to comment on and decide on policy issues. It has also provided guidance to other branches of government as to how such matters are to be dealt with. A good example of such a case is that of the Treatment Action Campaign. ${ }^{50}$ In this case, the constitutionality of a programme put in place by government to help with the prevention of HIV transmission from mother to child was challenged by a non-governmental organisation. This programme was confined to only two areas, one in the rural areas and the other in an urban area. Doctors who were outside these piloted areas did not have access to Nevirapine, which was the preferred anti-retroviral drug. The High Court ordered the government to make the drug available to all HIV-positive mothers and children at birth. The Court further ordered that the government develop and put into place a comprehensive plan which would help prevent mother-to-child transmission.

\footnotetext{
47 Du Plessis and De Ville 1993 Stell LR81.

48 Dugard Human Rights 367.

49 Dugard Human Rights 368.

50 Minister of Health v Treatment Action Campaign 200210 BCLR 1033 (CC).
} 
The Constitutional Court upheld the decision of the High Court on appeal. Even though the Constitutional Court agreed that the primary policy formulators should be the parliament and the executive, it stated that the courts were also mandated to make decisions that might impact or affect policy. ${ }^{51}$ Where policies were challenged as being inconsistent with the Constitution, courts would have to consider whether in implementing and formulating these policies the state had given effect to its constitutional obligations. If the Court found that the state had failed to act accordingly, it was under an obligation to say so. ${ }^{52}$ As much as this constituted an intrusion into the domain of the executive, it was an intrusion required by the Constitution. Further, if the government was found to be in breach of its obligations as required by the Constitution, it was necessary for the Court to provide appropriate relief to remedy the breach. In so formulating that relief, there was a need to ensure that constitutional rights were vindicated. Further, the Court would need to be attentive to both to the functions of the legislature and the executive under the Constitution. ${ }^{53}$

In Grootboom ${ }^{54}$ the Court directed the government to implement a coordinated and comprehensive programme within its available resources to progressively realise the right of access to adequate housing ${ }^{55}$ In doing this the Court entered the domain of the executive and made a decision that affected policy. This decision was clearly a deviation from the Soobramoney decision, where the Court refused lifesaving dialysis treatment to the applicant because of budgetary constraints. The Constitutional Court rejected the applicant's contention that this treatment qualified as emergency medical treatment under section $27(3)^{56}$ of the Constitution. In this case the Court declared that it would be slow to "interfere with rational decisions taken in good faith by the political organs". 57

However, a failure by a court to fulfil its mandate of promoting the spirit, purport and objects of the Bill of Rights by deferring to the legislature could potentially leave certain rights unprotected or with little protection. This can be especially argued for in cases where minority rights are affected. This was seen in the Fourie case, where the Court suspended section 30(1) of

\footnotetext{
51 Minister of Health $v$ Treatment Action Campaign 200210 BCLR 1033 (CC).

52 This is consistent with ss $165(2)$ and 7(2) of the Constitution.

53 Minister of Health $v$ Treatment Action Campaign 200210 BCLR 1033 (CC).

54 Government of the Republic of South Africa v Grootboom 200011 BCLR 1169 (CC).

55 Government of the Republic of South Africa v Grootboom 200011 BCLR 1169 (CC).

56 Section 27(3) of the Constitution provides that "No one may be refused emergency medical treatment".

57 Soobramoney v Minister of Health, KwaZulu-Natal 19981 SA 765 (CC).
} 
the Marriage Act. This was so as to give the legislature adequate time to remedy the defect invalidated by the Court's judgment. However, this also resulted in the deferring of equality rights of same-sex couples for one year. The Court could have simply ordered that there be a reading in of the words "or spouse" to section 30(1) of the Marriage Act, and as argued by Justice $O$ ' Regan in her dissenting judgment, this

would not create great uncertainty when the legislation was eventually amended in favour of same-sex marriages and neither would reading in obstruct the legislature in its policy choices. ${ }^{58}$

Masiya also shows that the Court's deference to the legislature has the effect of defeating its mandate of protecting minorities. In his dissenting judgment, Langa CJ stated that "young boys, prisoners and homosexuals", who are "most often the survivors of rape, are, like women, also vulnerable groups in our society". 59 Therefore, the refusal by the Court to extend the common law definition of rape to include non-consensual male-on-male penetrative sex arguably constituted a failure to fulfil its mandate and role as the guardian of the Constitution. Justice Susan Kenny from Australia states that

As trustees of the law, the judiciary administers the law not for its own benefit but for the benefit of each and every member of the community. The public, then, is the whole community - which at times may not be represented by the majority or the media. ${ }^{60}$

It is submitted that in these cases the Court did not adequately protect the minorities, who are represented by neither the public nor the media. Therefore, where the judges are faced with such hard cases there must be a consideration of minority rights and how these may be affected by the relevant policies or laws. This is because these minorities are usually not well represented in the relevant decision-making forums and are therefore essentially disempowered. However, their fundamental rights must still be protected.

In cases where the courts declare any legislation unconstitutional and subsequently invalidate such legislation in a bid to protect certain rights, courts should then employ modificative interpretation without reluctance, unless that would impose an unnecessary burden on government or grossly interfere with existing laws. Further, the court should also make an

58 Minister of Home Affairs $v$ Fourie; Lesbian and Gay Equality Project $v$ Minister of Home Affairs 20061 SA 524 (CC).

59 Masiya $v$ Director of Public Prosecutions (Pretoria) 20075 SA 30 (CC) 86.

60 Kenny 1999 Monash U L Rev 210. 
assessment as to whether there is a less intrusive manner of deciding the matter, taking into consideration the doctrine of the separation of powers. Modificative interpretation allows for the adoption of an interpretation that modifies the meaning of certain legislation. This would aid in not leaving rights unprotected or a lacuna in the law as a result of deference by the courts. This can be done through:

1. reading in, which entails reading words into a provision so as to make it constitutional;

2. reading down, which is a more restrictive method of interpretation allowing the courts to adopt an interpretation that will be deemed to be constitutional where legislation is unconstitutional at face value but is capable of being interpreted in a constitutional manner;

3. finally, severance, which involves the elimination of an offending part of a provision so as to render it constitutional and valid. ${ }^{61}$

In all this, a certain balance needs to be struck in matters involving the constitutionality of legislation or policies. Criticisms of judicial activism have resulted in the judiciary, as we have seen in some instances, being extremely sensitive to the thin boundary between exercising those powers which they have been constitutionally mandated to exercise and legislating from the bench. Justice O'Regan in Bertie Van $Z y^{162}$ cited a passage from the Court's judgment in Hyundai:

On the one hand, it is the duty of a judicial officer to interpret legislation in conformity with the Constitution so far as this is reasonably possible. On the other hand, the legislature is under a duty to pass legislation that is reasonably clear and precise, enabling citizens and officials to understand what is expected of them. A balance will have to be struck as to how this tension is to be resolved when considering the constitutionality of legislation. ${ }^{63}$

Judicial duty demands the delivery of justice. In the South African context, it is submitted that such justice can be achieved through the correct methodology of interpretation, which has been identified as a valueactivating or teleological method of interpretation. This methodology should inform the way we interpret legislation and the Constitution with the values that it epitomises in a constitutional democracy. The correct interpretation of section 39(2) of the Constitution mandates that the courts

61 Botha Statutory Interpretation 195-197.

62 Bertie Van Zyl (Pty) Ltd v Minister for Safety and Security 200910 BCLR 978 (CC).

63 Investigating Directorate: Serious Economic Offences v Hyundai Motor Distributors (Pty) Ltd: In Re: Hyundai Motor Distributors (Pty) Ltd v Smit 200010 BCLR 1079 (CC). 
are to promote the spirit, purport and objects of the Bill of Rights. This, it is argued, is a cue for the courts to engage in judicial activism, but only for as long as it protects or promotes the rights contained in the Bill of Rights. Judges do not have an unlimited discretion, but one that is likened to the hole at the centre of a doughnut by Dworkin. ${ }^{64}$ It is one that can be applied only if the surrounding belt of restriction ${ }^{65}$ is taken cognisance of.

\section{Conclusion}

Engaging in judicial activism can be controversial and can strain the relations between the judiciary and other branches of the government. However, Du Plessis and Wesson state that all

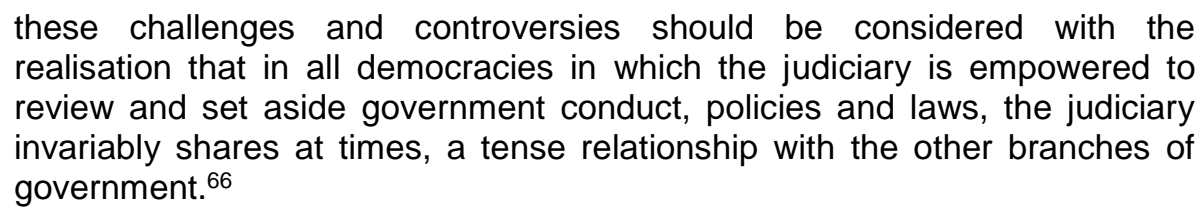
realisation that in all democracies in which the judiciary is empowered to review and set aside government conduct, policies and laws, the judiciary invariably shares at times, a tense relationship with the other branches of government. ${ }^{66}$

Although judicial activism may appear to be contrary to the doctrine of the separation of powers, it is an important part of judicial review. Judicial review is consistent with the checks and balances mechanism, which is an element of the doctrine of the separation of powers. Judicial activism could therefore be viewed as a way of ensuring that the exercise of power by other branches of government does not go unchecked.

It is appreciated that the excessive exercise of judicial activism might result in the judiciary's overstepping boundaries and fully taking on the roles of the policy and law makers, and thereby hindering the executive from effectively implementing its policies and the legislature from fulfilling its function of law-making. It is suggested that the courts should then formulate a test that could assist the courts in determining whether a case is one that requires it to engage in judicial activism. The courts could perhaps take the following factors into account when deciding whether or not to engage in judicial activism:

1. The nature of the right. This entails taking into consideration whether such rights are strongly protected by the Constitution, for example, equality, access to courts, just administrative action or dignity. If so,

\footnotetext{
64 Johnson, Pete and Du Plessis Jurisprudence 119.

65 The restrictions on this discretion in the South African context are the values, purport, object and spirit of the Constitution.

66 Wesson and Du Plessis 2005 http://bit.ly/21Lz2L5.
} 
then the court, as the guardian of the Constitution, must take all the necessary measures to protect such rights.

2. Whether the issue involves consideration of social, economic or political factors and if so, to what extent. Where an issue is likely to have grossly adverse implications on these factors then the courts should lean towards engaging in activism so as to remedy the situation and prevent such an effect. It is apparent in our discussion that this factor was a key consideration in the Grootboom and Treatment Action Campaign cases.

3. Whether a minority group is adversely affected. Considering, minority groups are not adequately represented in the relevant decision making institutions, the courts should take this factor into consideration so as to protect such minorities. This position was adopted and applied in respect of the Fourie case discussed above.

4. Whether the failure to decide on such a matter would result in a gross injustice and/or leave certain rights unprotected. Where there is the possibility of a gross injustice or a chance that certain fundamental rights might be left unprotected, then the court should take this as a factor weighing in favour of engaging in judicial activism. It is quite evident from the Masiya case, which is discussed above, that this is a factor that the courts need to seriously consider.

5. Whether there is a less intrusive manner of protecting such rights whilst still observing the doctrine of the separation of powers. Where there are less intrusive ways of enforcing or protecting rights, then the court should adopt those. Failure to do this would result in an abuse of the Court's power of judicial review and the arbitrary adoption of judicial activism.

In conclusion, what is evident is that it is crucial for the development of our constitutional democracy that the courts engage in judicial activism. Further, such powers are granted to the judges in terms of section 39(2) of the Constitution. The application of section 39(2) has resulted in a new value-based jurisprudence, as opposed to the legal positivism that prevailed prior to the Constitution. This is akin to natural law. As such, judges must unlock the creative powers granted to them in the Constitution and should consider the aforementioned factors before making decisions that will affect other branches of government. It is submitted that a consideration of the factors highlighted above is not only 
relevant in the process of judicial law-making, but is what is expected of judges in unlocking the creative powers encapsulated in section 39(2).

\section{Bibliography}

\section{Literature}

Bennion Statutory Interpretation

Bennion F Statutory Interpretation $5^{\text {th }}$ ed (Lexis Nexis London 2010)

Bickel Least Dangerous Branch

Bickel AM The Least Dangerous Branch $2^{\text {nd }}$ ed (New Haven Yale University Press 1986)

Botha Statutory Interpretation

Botha C Statutory Interpretation (Juta Cape Town 2005)

Cross Statutory Interpretation

Cross R Statutory Interpretation $3^{\text {rd }}$ ed (Butterworths London 1995)

Devenish Interpretation of Statutes

Devenish GE Interpretation of Statutes (Juta Cape Town 1992)

Dicey Introduction to the Study of Law

Dicey AV Introduction to the Study of Law and the Constitution (Macmillan London 1915)

Du Plessis Re-Interpretation of Statutes

Du Plessis LM Re-Interpretation of Statutes (Lexis Nexis Durban 2002)

Du Plessis and De Ville 1993 Stell $L R$

Du Plessis LM and De Ville JR "Bill of Rights in the South African Context (1): Diagnostic Observations" 1993 Stell LR63-87

Dugard Human Rights

Dugard J Human Rights and the South African Legal Order (Princeton University Press Princeton, NJ 1978)

Friedman 1961 Colum L Rev

Friedman W "Legal Philosophy and Judicial Law-making" 1961 Colum L Rev 821-845 
Graglia 1996 Harv J L \& Pub Pol'y

Graglia LA "It's Not Constitutionalism, It's Judicial Activism" 1996 Harv J L \& Pub Pol'y 293-300

Hart 1958 Harv L Rev

Hart HLA "Positivism and the Separation of Law and Morals" 1958 Harv L Rev 593-621

Johnson, Pete and Du Plessis Jurisprudence

Johnson D, Pete S and Du Plessis M Jurisprudence: A South African Perspective (Butterworths Durban 2001)

Kenny 1999 Monash U L Rev

Kenny S "Maintaining Public Confidence in the Judiciary: A Precarious Equilibrium" 1999 Monash U L Rev 209-224

Mahomed 1999 SALJ

Mahomed CJ "The Role of the Judiciary in a Constitutional State" 1999 SALJ 111-115

Rosenfield Law, Justice, Democracy

Rosenfield M Law, Justice, Democracy and the Clash of Cultures (Cambridge University Press Cambridge 2011)

Sowell Judicial Activism Reconsidered

Sowell T Judicial Activism Reconsidered (Stanford University Stanford, CA 1989)

\section{Case law}

Bertie Van Zyl (Pty) Ltd v Minister of Safety and Security 200910 BCLR 978 (CC)

Coetzee $v$ Government of the Republic of South Africa, Matiso $v$ Commanding Officer, Port Elizabeth Prison 199510 BCLR 1382 (CC)

Collins v Minister of the Interior 19571 SA 552 (A)

Corocraft Ltd v Pan American Airways 19733 (WLR) 714

Government of the Republic of South Africa v Grootboom 200011 BCLR 1169 (CC) 
Investigating Directorate: Serious Economic Offences v Hyundai Motor Distributors (Pty) Ltd: In Re: Hyundai Motor Distributors (Pty) Ltd v Smit and 200010 BCLR 1079 (CC)

Masiya v Director of Public Prosecutions (Pretoria) 20075 SA 30 (CC)

Minister of Health v Treatment Action Campaign 200610 BCLR 1033 (CC)

Minister of Home Affairs $v$ Fourie; Lesbian and Gay Equality Project $v$ Minister of Home Affairs 20061 SA 524 (CC)

Minister of Posts and Telegraphs v Rasool 1934 AD 164

Prince $v$ President of the Law Society of the Cape of Good Hope 20022 SA 194 (CC)

S v Hjul 19642 SA 635 (C)

S v Makwanyane 19953 SA 391 (CC)

$S v$ Tobias 19672 SA $165(C)$

$S v$ Wood 19761 SA 703 (AD)

Soobramoney v Minister of Health, KwaZulu Natal 19981 SA 765 (CC)

Stanton v Minister of Justice 19643 SA 354 (T)

\section{Legislation}

Constitution of the Republic of South Africa Act 200 of 1993

Constitution of the Republic of South Africa, 1996

Criminal Procedure Act 51 of 1997

Marriage Act 25 of 1961

\section{Internet sources}

Cornell and Friedman 2002 http://bit.ly/24FjjPu

Cornell D and Friedman N 2002 In Defence of the Constitutional Court Human Rights and the South African Common Law http://bit.ly/24FjjPu accessed 22 November 2012 
Diala 2007 http://bit.ly/1SZ17c6

Diala AC 2007 Judicial Activism in South Africa's Constitutional Court: Minority Protection or Judicial Illegitimacy http://bit.ly/1SZ17c6 accessed 22 November 2012

Quansah and Fombad 2009 http://bit.ly/24E8Ffj

Quansah EK and Fombad CM 2009 Judicial Activism in Africa: Possible Defence Against Authoritarian Resurgence? http://bit.ly/24E8Ffj accessed 5 December 2012

Wesson and Du Plessis 2005 http://bit.ly/21Lz2L5

Wesson M and Du Plessis M 2005 The Transformation of the Judiciary http://bit.ly/21Lz2L5 accessed 4 January 2013

\section{List of Abbreviations}

Colum L Rev

Harv J L \& Pub Pol'y

Harv L Rev

Monash U L Rev

SALJ

Stell LR
Columbia Law Review

Harvard Journal of Law and Public Policy

Harvard Law Review

Monash University Law Review

South African Law Journal

Stellenbosch Law Review 